\title{
First record of Astrocaryum G. Mey. (Arecaceae) for Ceará, Northeastern Brazil
}

\author{
Leonardo de Sousa Rodrigues ${ }^{*} \bullet$, Izaias Carvalho de Sousab®, Francisco Diego Sousa Santosc®, \\ Elnatan Bezerra de Souzaa
}

\author{
a Universidade Estadual Vale do Acaraú, Sobral,62040-370, Ceará, Brasil.*leosouzarodrigues85@gmail.com \\ b Programa de Pós-Graduação em Agronomia, Universidade Estadual Paulista, Ilha Solteira, 15385-000, São Paulo, Brasil. \\ c Programa de Pós-Graduação em Botânica, Universidade Federal Rural de Pernambuco, Recife, 52171-030, Pernambuco, Brasil.
}

Received: November 16, 2021 / Accepted: January 27, 2022 / Published online: January 31, 2022

\begin{abstract}
We document here the first record of Astrocaryum G.Mey. for Ceará State, Brazil. A. vulgare Mart., a species formerly known only to the Brazilian states of Amapá, Pará, Tocantins, Goiás, and Maranhão, was collected in areas of the Coastal Vegetation Complex, whose floristic composition is influenced by both the Caatinga and Cerrado domains. This finding expands our knowledge on the geographic distribution of this species in Brazil, contributing to its conservation and to future biogeographic studies. We present ecological, morphological and taxonomic data, a distribution map, photographs and illustrations, and update its conservation status.
\end{abstract}

Keywords: Coastal vegetation; conservation; ecotone; geographic distribution; Palmae.

\section{Primeiro registro de Astrocaryum G. Mey. (Arecaceae) no Ceará, Nordeste do Brasil}

\begin{abstract}
Resumo
Este estudo reporta o primeiro registro de Astrocaryum G.Mey. para o estado do Ceará, Brasil. A. vulgare Mart., uma espécie conhecida apenas para os estados brasileiros de Amapá, Pará, Tocantins, Goiás e Maranhão. Foi coletada em áreas do Complexo Vegetacional Litorâneo, cuja composição florística é influenciada pelos domínios da Caatinga e Cerrado. Este achado amplia o nosso conhecimento sobre a distribuição geográfica desta espécie no Brasil, contribuindo para sua conservação e futuros estudos biogeográficos. Apresentamos, dados ecológicos, morfológicos e taxonômicos, mapa de distribuição, fotografias e ilustrações e seu status de conservação atualizado.
\end{abstract}

Palavras-chave: Vegetação costeira; conservação, ecotono; distribuição geográfica; Palmae.

The genus Astrocaryum G. Mey. comprises 40 species with Neotropical distributions, mainly in South America. The genus is represented by 23 species in Brazil, with representatives being found in the Amazon, Caatinga, Cerrado, and Atlantic Forest domains in several vegetation formations. Astrocaryum is represented by five species in northeastern Brazil, and has been reported there in the states of Bahia, Maranhão, and Piauí (Vianna, 2020). The genus is characterized as comprising monoecious palms, with woody stipes, simple or caespitose, and stem subterranean or aerial, with black, flat, and long spines (Kahn \& Granville, 1992).

During field trips to Ceará State, Astrocaryum specimens were encountered having multiple stipes $4.0-10 \mathrm{~m}$ tall, $10-20$ $\mathrm{cm}$ in diameter, and covered by spines. Consultations of the specialized literature (Henderson et al., 1995) indicated that those plants were $A$. vulgare Mart., which had previously only been reported for Goiás State in the Midwest region, in the states of Tocantins, Amapá and Pará in the north region, and in the Maranhão State in the northeast region (Vianna, 2020).

Information concerning a species' distribution is essential to understanding the dynamics of plant communities (Whittaker et al., 2005) and for making decisions concerning their conservation - as a plant's distribution indicates the size of the area it occupies, which is used as one criterion for assessing its risk of extinction (Marinho \& Beech, 2020). We therefore report here the first occurrence of Astrocaryum in the flora of Ceará State, and expand knowledge about the distribution of $A$. vulgare.

Ceará State, located in northeastern Brazil, is bordered to the north by the Atlantic Ocean, to the south by Pernambuco State, to the east by the states of Rio Grande do Norte and Paraiba, and to the west by Piauí State; it covers an area of $148,894 \mathrm{~km}^{2}$ (IBGE, 2016). This study was based on field trips undertaken between August/2020 and August/2021, and consultations of the collections of the Prisco Bezerra (EAC), Caririense Dárdano de Andrade-Lima (HCDAL), and Professor Francisco José de Abreu Matos (HUVA) herbaria, as well as online data platforms (SpeciesLink, Flora do Brasil 2020) - acronyms following Thiers (2021). The identification of the species was based on the specialized 
literature (Henderson et al., 1995) and was confirmed by the analysis of its holotype (available on the Jstor site; https://plants.jstor.org/). The vegetative description and the characterization of its pistillate and staminate flowers follow Henderson et al. (1995); the description of the floral whorls follows Uhl and Dransfield (1987). The geographic distribution map was prepared using QGIS Software, and the diagnostic features were illustrated.

Astrocaryum vulgare Mart., Hist. Nat. Palm. 2: 74, pl. 62-63. 1824. (Figures. 1 e 2)

Type: Brazil. Pará, unspecified location, s.d. Martius s.n. (holotype, M [Barcode 0209583; digital image!]).

Stipe caespitose, 4-10 $\mathrm{m}$ height, $10-20 \mathrm{~cm}$ in diameter, covered with spines on the nodes and internodes. Leaves pinnate, 7-17, irregularly arranged, 16-35 cm long, glabrous; petiole 2-3 m long, glabrous, with spines; leaf rachis up to 3.5 $\mathrm{m}$ long, $80-115$ pairs of pins, $0.70-1.15 \times 1.5-4.0 \mathrm{~cm}$; adaxial surface green, abaxial surface whitish, glabrous, arranged in different planes. Inflorescence interfoliar, erect; bract pedunculate, up to $1.8 \mathrm{~m}$ long, with spines; peduncle $10-50 \mathrm{~cm}$ long, rachis 30-80 cm long, with spines; rachillae > 100 . Flowers with pistil 3-1.5 $\times 0.7-0.8 \mathrm{~cm}$, sessile, $2-5$ in the basal region of the rachillae. Calyx $0.7-0.9 \times 0.6-0.8 \mathrm{~cm}$, persistent, cream, calyx and corolla imbricate, urceolate; corolla $0.6-0.8 \times$ $0.5-0.7 \mathrm{~cm}$, persistent, beige, stigma trifid, $0.5-0.7 \times 0.2-0.3$ $\mathrm{cm}$; ovary, 0.2-0.4 × 0.4-0.5 cm, cream colored. Flowers with stamen sessile, $0.4-0.6 \times 0.4-0.5 \mathrm{~cm}$, numerous in the distal portion of the rachilla, inconspicuous; corolla $0.4-0.6 \times 0.2-0.4$ $\mathrm{cm}$, beige; fillets violet, anthers dorsifix, $0.2-0.3 \times 0.1-0.3 \mathrm{~cm}$, beige, with longitudinal dehiscence. Fruits $3.5-5 \times 2.5-3.7 \mathrm{~cm}$, globoid or ellipsoidal, indehiscent; epicarp smooth, orange or reddish; mesocarp orange and fleshy; endocarp hard and black; endosperm homogeneous, with cavity.

Taxonomic notes: A. vulgare is known for its caespitose habit, with stipes with long spines along the internodes. It can be confused with A. huaimi Mart., as they share: multiple stipes; spines in the nodes and internodes; irregularly arranged leaves in different planes; inflorescence and infructescence erect; 2-5 pistillate flowers; fruits indehiscent with epicarp smooth and orange. Those similarities had already been reported by Henderson (1995), who noted that the two taxa were difficult to distinguish. A. vulgare can be differed from $A$. huaimi, however, by its greater density of spines in the peduncular bract (vs. lower density of spines in A. huaimi), and greater numbers of rachillae, $>100$ (vs. up to 70 rachillae).

Distribution and conservation notes: A. vulgare occurs in French Guiana, Guyana, Suriname (Henderson et al., 1995), and in midwestern (Goiás State), northern (Amapá, Pará, and Tocantins states), and northeastern Brazil - where it was only previously known for Maranhão State, in the Cerrado and Amazon domains (Flora do Brasil, 2020). It occurs in the Coastal Vegetation Complex in Ceará State in the municipalities of Itapipoca and Jijoca de Jericoacoara, and in cerrado enclaves in the municipality of Camocim (Figure 3). These new areas of occurrence of $A$. vulgare are under the influence of distinuritct edaphoclimatic and geomorphological conditions (resulting in the floristic heterogeneity observed in those environments). Parts of those areas have been impacted by anthropic interventions, which emphasizes the importance of the Jijoca de Jericoacoara National Park and the Mundaú River Estuary Environmental Protection Area to the preservation of $A$. vulgare.

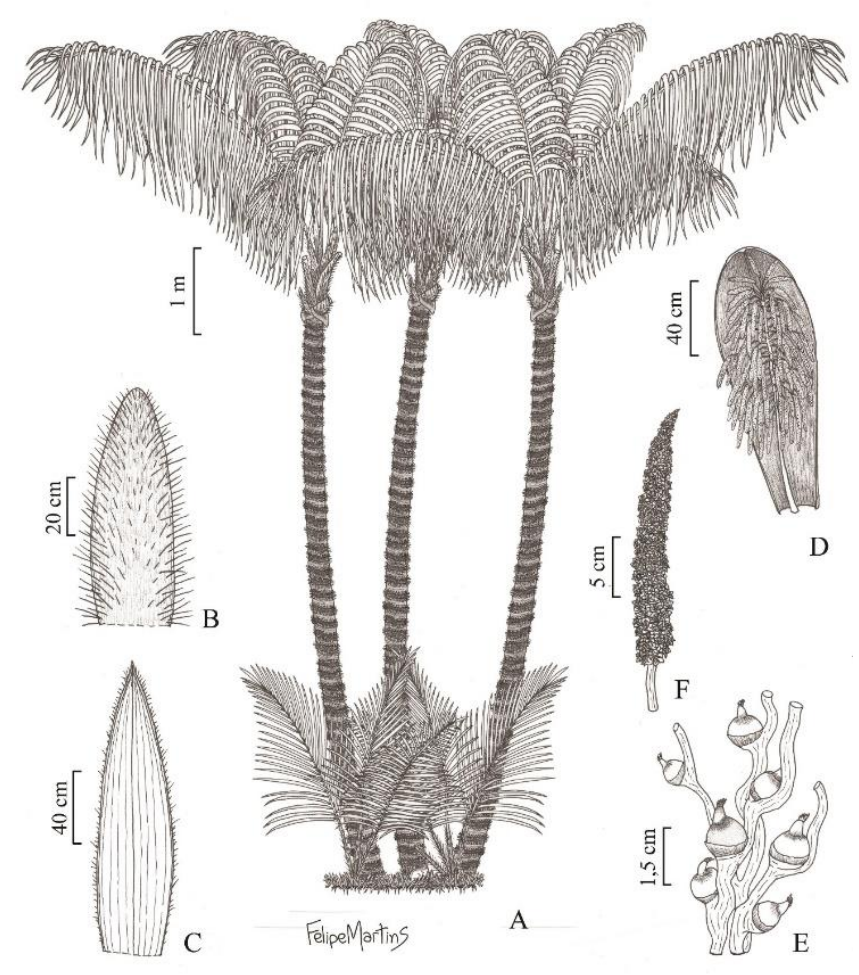

Figure 1. Astrocaryum vulgare. A. Habit with stipe woody, caespitose; B. Bract (upper view); C. Bract (lower view); D. Inflorescence and bract; E. Pistillate flowers in the proximal region of the rachilla; F. Details of staminate flowers in the terminal region of the rachilla. L.S. Rodrigues 02 .

Material examined: BRASIL, Ceará: Itapipoca (3.290147, -39.521542), altitude $200 \mathrm{~m}, 17 . X .2020$; L.S. Rodrigues 02 (HUVA); Jijoca de Jericoacoara National Park (-2.859492, -40.456899), altitude $18 \mathrm{~m}, 11$. VII.2021, L.S. Rodrigues 111 (HUVA); Camocim (-2.927687, 40.958587), altitude 9 m, 04.VIII.2021, L. S. Rodrigues 119 (HUVA).

A. vulgare is a component species of Cerrado vegetation (Vianna, 2020). It is frequently found in white sand savannas in countries such as Suriname, in disturbed areas, and at low elevations (Henderson et al., 1995). It occurs in the Amazon, Cerrado, and Caatinga domains, and is common in the Vegetation Complex of the Coastal Zone in Ceará State. That vegetation complex harbors several species typical of the Caatinga and Cerrado domains - suggesting its ecotonal nature (Castro et al., 2012, Moro et al., 2011).

The occurrence of typical cerrado species in the Coastal Vegetation Complex reflects its mild climate and deep soils (Figueiredo \& Fernandes, 1987). 


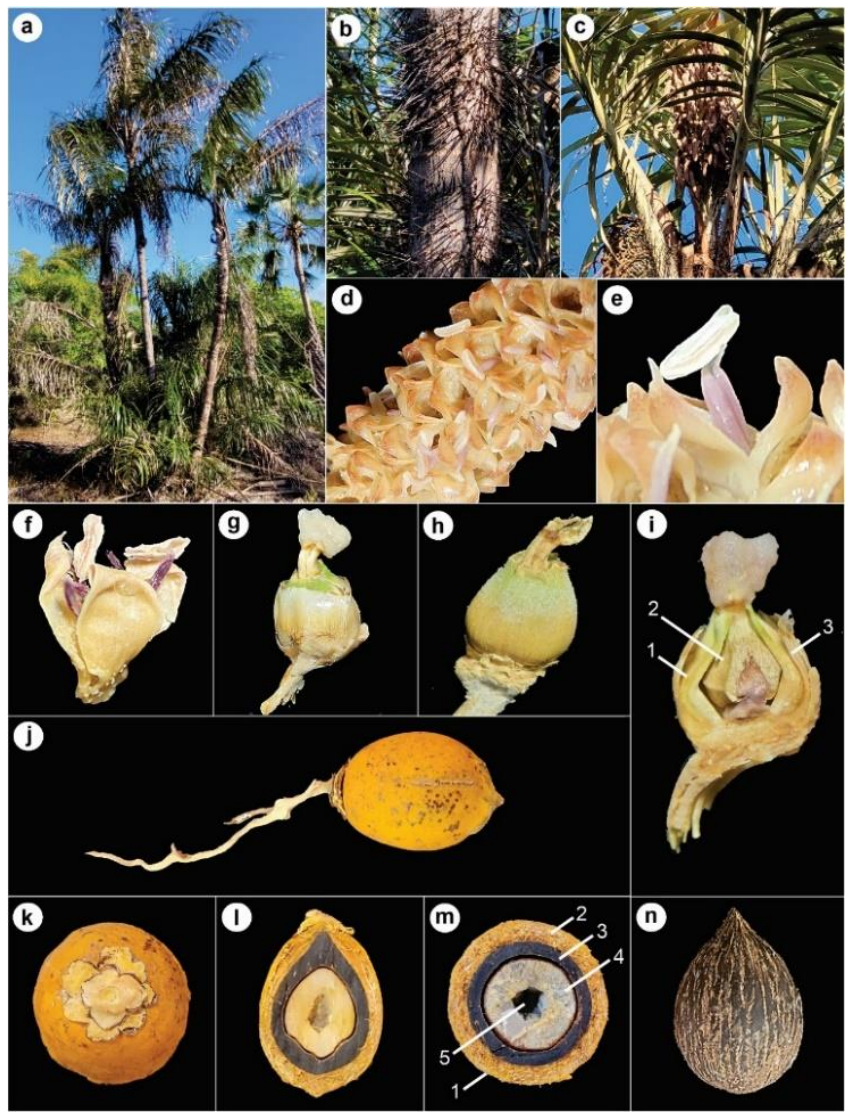

Figure 2. Diagnostic characters of Astrocaryum vulgare. a. Habit caespitose; b. Nodes and internodes with spines; c. Inflorescence interfoliar; d. Staminate flowers on the rachilla; e. Anther; f. Detail of the staminate flowers, g. Pistillate flowers, h. Pistillate flower with urceolate corolla, i. Detail of a pistillate flower (1. calyx; 2. corolla; 3 . pistil), j. Fruit in the rachilla; k. Fruit; 1. Fruit in longitudinal cut; m. Fruit details in cross section (1. epicarp 2. mesocarp; 3. endocarp; 4. endosperm; 5. Endosperm cavity); n. endocarp. Photos: L.S. Rodrigues.

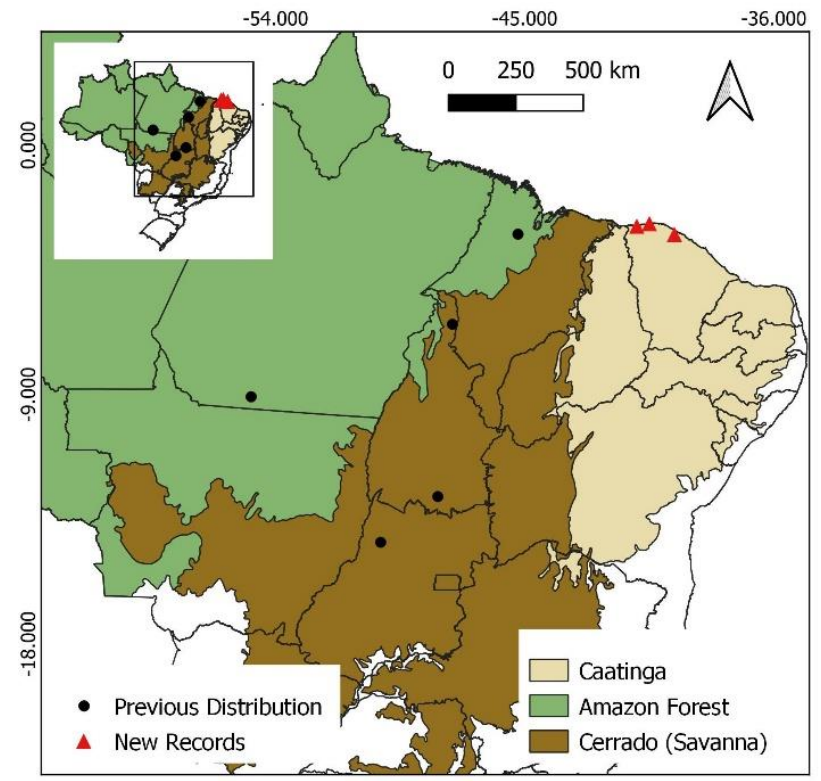

Figure 3. Updated geographic distribution of Astrocaryum vulgare in Brazil, highlighting its new occurrence.
The occurrence of $A$. vulgare in the floristic composition of this phytoecological area in Ceará State reinforces the influence of Cerrado vegetation and highlights the need for more floristic studies in those little known and highly threatened sites, and the necessity for more information concerning their phytogeographic relationships that could aid in their conservation.

\section{Acknowledgment}

We would like to thank the Fundação Cearense de Apoio ao Desenvolvimento Científico e Tecnológico (FUNCAP) for funding the research and for the scientific initiation scholarship awarded to the first author (Process BP4-017200170.01.00/20); Francisca Barbosa Carvalho for her cooperation during the field work; and Germana Álvares de Carvalho and Ana Maria Álvares for their support during the collections in Camocim.

\section{References}

Castro, A. S. F., Moro, M. F., \& Menezes, M. D. (2012). O complexo vegetacional da zona litorânea no Ceará: Pecém, São Gonçalo do Amarante. Acta Botanica Brasilica, (26), 108-124. doi: $10.1590 /$ S0102-33062012000100013

Figueiredo, \& M. A., Fernandes, A. (1987). Encraves de cerrado no interior do Ceará. Ciência Agronomica, 18(2), 103-106.

Flora do Brasil. (2020) Jardim Botânico do Rio de Janeiro. Recovered from http://floradobrasil.jbrj.gov.br/reflora/

Henderson, A., Galeano, G., \& Bernal, R. (1995). Field guide to the palms of the Americas. (1a. ed.). Princeton: Princeton University Press.

IBGE. (2016). Atlas Nacional Digital do Brasil 2016. Instituto Brasileiro de Geografia e Estatística, Brasilia. Recovered from http://www.ibge.gov.br/apps/atlas_nacional

SpeciesLink. (2021). SpeciesLink. Recovered from http://www.splink.org.br.

JSTOR - Global Plants (2020). Recovered from https://plants.jstor.org/stable/10.5555/al.ap.specimen.m0209582?searc hUri=filter\%3Dname\%26so\%3Dps_group_by_genus_species\%2Basc \%26Query\%3Dastrocaryum\%2Bvulgare.

Kahn, F., \& Granville, J. (1992). Palms in forest Ecosystems of Amazonia. (1a. ed.). Heidelberg: Springer Verlag,

Marinho, L. C. \& Beech, E. (2020). How phantom databases could contribute to conservation assessments. The Science of Nature, 107(3), 1-5. doi: 10.1007/s00114-020-01679-w

Moro, M. F., Castro, A. S. F., \& Araújo, F. S. (2011). Composição florística e estrutura de um fragmento de vegetação savânica sobre os tabuleiros pré-litorâneos na zona urbana de Fortaleza, Ceará. Rodriguésia, 62, 400-420. doi: 10.1590/2175-7860201162214

QGIS.org (2017). Geographic Information System. Open Source Geospatial Foundation Project. Recovered from https://qgis.org.

Thiers, B. (2021 [continuously updated]). Index Herbariorum: A global directory of public herbaria and Associated staff. New York Botanical Garden's Virtual Herbarium.

Uhl, N. W., \& Dransfield, J. (1987). Genera Palmarum: a classification of palms based on the work of Harold E. Moore Jr. Lawrence, Kansas: The L. H. Bailey Hortorium and the International Palm Society.

Vianna, S. A. (2020). Astrocaryum in Flora do Brasil 2020 (em construção). Rio de Janeiro: Instituto de Pesquisas Jardim Botânico do Rio de Janeiro. $\quad$ Recovered from http://floradobrasil.jbrj.gov.br/reflora/floradobrasil/FB15670

Whittaker, R. J., Araújo, M. B., Jepson, P., Ladle, R. J., Watson, J. M. E., \& Willis, K.J. (2005). Conservation biogeography: assessment and prospect. Diversity and distribution, 11, 3-23. 
Rodrigues, et al. - First record of Astrocaryum for Ceará, Brazil

This article was published with open access for distribution under the terms of the Creative Commons Attribution License, which allows unrestricted use, distribution, and reproduction in any medium, provided the original work is properly cited. 